\title{
Anisakiasis Pada Ikan Laut Di Indonesia: Prevalensi, Sebaran Dan Potensi Patogenitasnya Pada Manusia
}

\author{
Forman Erwin Siagian, ${ }^{1 *}$ Esy Maryanti ${ }^{2}$
}

\begin{abstract}
Nematode worm Anisakis sp is the causative agent of anisakiasis, a zoonosis which continues to be a health problem in humans, globally. Its clinical spectum varies from mild to very severe and always connected with sea fishes, one important source of nutrition for the community that cannot be ignored. In addition, consumer's behavior and lifestyle in processing and consuming sea fishes also have has the potency as the predisposing factor for its transmission and clinical manifestations. This review article aimed to describes recent global data on anisakiasis and its occurrence in marine fishes of Indonesian waters and the risk of transmission in the community.
\end{abstract}

Keywords: nematode, fillet, sushi, zoonosis, morphology, heating, cooling

Anisakiasis adalah penyakit zoonosis yang disebabkan oleh cacing nematoda dari famili Anisakidae, terutama Anisakis sp. ${ }^{1}$ Penyakit ini berpotensi fatal pada manusia karena menimbulkan berbagai spektrum penyakit mulai dari reaksi alergi akibat larva (intra- dan atau ekstra-intestinal) hingga gangguan mekanik saluran cerna. ${ }^{2-4}$ Sumber infeksi utama pada manusia adalah karena mengkonsumsi ikan yang mengandung larva stadium III (L3) Anisakis sp dan dihidangkan mentah atau dimasak kurang matang. ${ }^{3,4}$ Kombinasi dari (1) upaya mendorong pola konsumsi produk laut di masyarakat dan (2) gaya kuliner tertentu (seperti sushi atau sashimi ala masakan Jepang) mungkin meningkatkan kejadian infeksi di masyarakat. ${ }^{5-7}$ Kedua hal tersebut mendorong individu yang memakan ikan laut jika terinfeksi larva L3 Anisakis sp dan tidak dimasak dengan baik seperti yang dimakan dalam keadaan setengah matang atau malah mentah kemudian dapat menyebabkan penyakit Anisakiasis., ${ }^{3,7}$ Gaya hidup saat ini, terutama dalam konteks kuliner, mendorong model konsumsi yang berisiko seperti yang diungkapkan sebelumnya. ${ }^{1,3,7}$ Perilaku masyarakat dalam mengkonsumsi ikan juga terkait dengan kebijakan yang diambil pemerintah misalnya

\footnotetext{
* Corresponding author : forman.siagian@uki.ac.id

1 Departemen Parasitologi, Fakultas Kedokteran Universitas Kristen Indonesia, Jakarta Indonesia,

2 KJFD Parasitologi, Fakultas Kedokteran Universitas Riau, Pekanbaru, Riau, Indonesia
}

melalui upaya program peningkatan konsumsi ikan nasional. ${ }^{6}$

Ikan yang banyak dilaporkan terinfeksi oleh larva cacing ini adalah ikan laut terutama ikan laut yang ditangkap di daerah dekat pantai atau pesisir. ${ }^{6,9}$ Hal tersebut telah banyak dikonfirmasi untuk wilayah beriklim tropis seperti Indonesia atau Asia tenggara maupun subtropis bahkan hingga wilayah beriklim dingin seperti di Laut Arktik. ${ }^{10}$ Rentang jangkauan dan dinamika sebaran parasit ini di dunia menunjukkan fenomena gunung es bagi konsumen dalam konteks prevalensi dan potensi patogenitas. ${ }^{8}$ Makalah ini bertujuan untuk mengulas mengenai anisakiasis secara umum dan pada ikan laut di wilayah perairan Indonesia dengan penekanan pada prevalensi, rentang sebaran, kualitas produk ikan yang terinfeksi dan potensi patogenitasnya pada manusia sebagai konsumen.

\section{ANISAKIASIS: MASALAH GLOBAL DENGAN FENOMENA GUNUNG ES}

Anisakiasis atau "herringworm" adalah infeksi oleh cacing nematoda Anisakis sp complex. ${ }^{7-9}$ Umumnya menginfeksi ikan laut dalam dengan karakteristik karnivora atau predator. ${ }^{8,11}$ Ikan dan invertebrata akuatik seperti cumi-cumi merupakan bentuk hospes perantara cacing Anisakid. ${ }^{7,8,11}$ Pada inang perantara tersebut, cacing ini berada pada tahap perkembangan larva stadium L3., ${ }^{3,5}$ Anisakis 
sp umumnya hidup dan ditemukan pada dinding usus, hati dan otot ikan sehingga pada ikan tersebut dapat langsung menimbulkan efek patologis dan jika ikan yang terinfeksi termakan oleh manusia dapat juga menimbulkan masalah kesehatan pada manusia tersebut (zoonosis). ${ }^{3,5,7}$

Spesies ikan laut yang terinfeksi cacing ini beragam dan sangat luas. Hal itu terjadi karena karakteristik pola spesifisitas hospesnya yang rendah, ${ }^{11}$ artinya cacing ini memiliki kemampuan menginfeksi banyak jenis ikan/ tidak terbatas hanya pada spesies ikan tertentu. Ikan-ikan laut seperti herring (Clupea harengus), mackerel (Scomber scombrus $L$ ), atlantic salmon (Salmo satar $L$ ), cod (Gadus morhua L), whiting (Merlangius merlangus) blue whiting, (Micromesistius poutassou (Risso)) dan masih banyak lagi spesies dalam kelompok teleosts dan cephalopod yang pernah dilaporkan dari berbagai belahan dunia terinfeksi oleh cacing nematoda ini. ${ }^{12}$ Ikan-ikan yang disebutkan sebelumnya merupakan ikan yang menjadi primadona komoditas laut di masyarakat global. ${ }^{13}$ Selain itu, ikan-ikan tersebut juga menjadi komoditas ekspor sehingga kemungkinan juga bisa sampai ke tempattempat dengan posisi geografis jauh dari lokasi awal habitat alamiahnya. ${ }^{8,12}$

Didalam genus Anisakis, terdapat beberapa spesies yang pernah diisolasi dari berbagai jenis ikan laut, secara kolektif disebut sebagai Anisakis simplex sensu lato (kelas Nematoda, Superfamily Ascaridoidea, subfamily Anisakinae). Adapun yang termasuk didalamnya adalah A. simplex (Rudolphi, 1809, det. Krabbe, 1878) sensu stricto, A. pegreffii (Campana-Rouget dan Biocca, 1955), A. typica (Diesing, 1860), A. ziphidarum (Paggi, Nascetti, Webb, Mattiucci, Cianchi dan Bullini, 1998), A. physeteris (Baylis, 1923), A. brevispiculata (Dollfus, 1968), A. paggiae (Mattiucci, Nascetti, Dailey, Webb, Barros, Cianchi and Bullini, 2005), A. kuekenthalii (Cobb, 1889), A. rosmari (Baylis, 1916), A. schupakovi (Mosgovoi, 1951) dan A. typica (Diesing, 1860). Diketahui terjadi hibridisasi antara A. simplex sensu stricto dan A. pegreffii. Selain itu, termasuk juga didalam kelas Anisakis $s p$ yaitu Pseudoterranova decipiens (Krabbe, 1878) dan Contracaecum osculatum (Rudolphi, 1802). ${ }^{14}$

Siklus hidup Anisakis sp, seperti kebanyakan cacing dalam kelas nematoda yang lain, rumit dan kompleks karena melibatkan beberapa spesies hospes yang berbeda seiring pematangan tahap perkembangannya. ${ }^{11}$ Karakteristik parasit yang multi-hospes, terlebih dalam konteks melibatkan perilaku predatorisme dan karnivora menyebabkan sebaran cakupan atau distribusi parasit menjadi makin luas seiring dengan pola pergerakan hospesnya. ${ }^{8,12,14}$ Dalam konteks ini, potensi kontaminasi terhadap lingkungan juga makin meningkat. ${ }^{7}$ Perilaku hospes dan viabilitas parasit dalam tubuh hospes juga menentukan distribusi parasit di alam. ${ }^{15}$ Jumlah atau densitas parasit dalam ikan merupakan parameter kuantitatif atas infeksi parasit pada suatu organisme, hal ini dipengaruhi oleh banyak faktor dan memiliki variasi karena sejumlah faktor biotik dan abiotik. ${ }^{8,15}$ Sebagai bagian dari efek parasitisme, jumlah atau densitas parasit juga dipengaruhi oleh faktor spesies yang tergantung kepada sejumlah karakteristik intrinsik parasit, hospes dan lingkungannya. ${ }^{8,16,17}$ Penelitian do Amarante et $a l^{16}$ mengkonfirmasi bahwa taxa Trematoda, Nematoda dan Cestoda sebagai kelompok endoparasit utama dalam kelompok ikan, merupakan taxa yang paling banyak jumlahnya menginfeksi ikan laut. Kebanyakan parasit tersebut memiliki siklus hidup kompleks dengan banyak hospes sehingga sebaran geografis infeksi amat luas. ${ }^{18}$ Jalur infeksi selalu bersifat tropik predatorik-karnivorik (memakan hewan dengan taraf lebih rendah) sehingga meningkatkan kemungkinan kumulasi infeksi oleh cacing dewasa dan stadium larvanya sekaligus. ${ }^{10-12}$ Hal ini memperkuat potensi infra populasinya, terutama untuk spesies Anisakis sp. ${ }^{11}$ Spesies cacing ini banyak ditemukan pada ikan-ikan yang ditangkap di laut dekat daerah pesisir. ${ }^{7,12,15,18}$

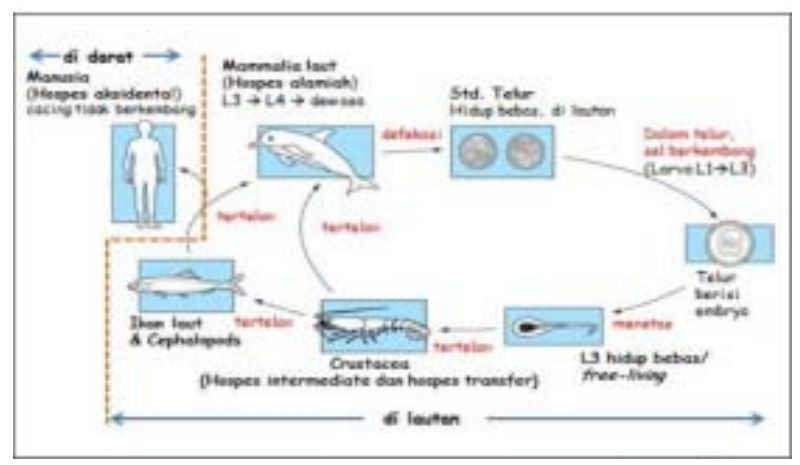

Gambar 1. Ilustrasi siklus hidup cacing nematode Anisakis spp. ${ }^{18, \text { dengan modifikasi }}$

Pada gambar 1. terlihat siklus hidup dari Anisakis sp. Telur dari cacing betina dewasa di 
dalam tubuh hospes mammalia dikeluarkan ke air laut dan untuk beberapa waktu berada dalam keadaan free-living. ${ }^{19}$ Seiring perkembangan isi telur yaitu sel telur ke arah stadium yang lebih matur yaitu menjadi larva, selanjutnya telur kemudian menetas dan larva keluar ke air lalu dikonsumsi oleh hospes invertebrata laut, biasanya dari golongan euphausids (zoo-plankton). ${ }^{18,19}$

Kemudian transmisi berlanjut ke hospes lain yang juga terjadi melalui moda konsumsi predatorisme euphausids yang sudah terinfeksi, biasanya oleh ikan-ikan yang berukuran lebih kecil dan cephalopods (misalnya gurita, cumi-cumi atau sotong) yang berperan sebagai hospes paratenik seiring perkembangan dari larva stadia II ke III terjadi pada euphausids. ${ }^{5,7,8,12}$ Mammalia laut mendapat infeksi akibat mengkonsumsi crustacean/kelompok udang-udangan, ikan atau kelompok cephalopods (misalnya gurita, cumi-cumi atau sotong) yang sudah lebih dahulu terinfeksi. ${ }^{20}$ Parasit dewasa dapat ditemukan pada pinnipeds (mammalia seperti anjing laut) dan cetacean (mammalia laut lain yang berukuran lebih besar seperti lumba-lumba atau pesut). ${ }^{21}$

Larva cacing ini sering ditemukan di organ dalam/viscera dan otot ikan serta kemudian dapat bermigrasi post-mortem dari rongga abdomen ke bagian daging/otot ikan, hal tersebut dapat terjadi selama larva cacing masih hidup. ${ }^{3,5,21}$ Penetrasi larva ke bagian otot yang lebih dalam inilah yang menyulitkan upaya untuk menginspeksi secara visual dengan mata telanjang keberadaan larva cacing nematoda ini. ${ }^{6,13}$ Selain itu, Mladineo et $a l^{22}$ menyatakan bahwa kontaminasi cacing pada produk ikan laut menurunkan nilai komersialisasinya di pasaran bahkan hingga dapat terjadi penolakan terhadap jenis tertentu, dalam konteks ekspor atau import.

Salah satu alternatif yang dapat dilakukan untuk mendapatkan gambaran yang lebih jelas adalah dengan melakukan insisi atau pemotongan model fillet/irisan tipis-tipis sehingga kemungkinan untuk mencapai posisi atau lokasi anatomis tempat keberadaan larva dalam otot menjadi lebih besar.,3,21 Selain itu, dengan melakukan irisan model ini, maka luas permukaan yang dapat dijangkau menjadi lebih terbuka dan lebih berpotensi untuk mendapat pemanasan saat dimasak sehingga potensi untuk mematikan larva juga menjadi lebih baik. Meskipun ada kekhawatiran, membuat potongan secara fillet justru mengekspos/membuka larva yang tadinya terkurung didalam jaringan otot ikan. Hingga saat ini belum ada metode yang dianggap superior dalam mendeteksi keberadaan cacing ini dalam komoditas ikan laut. ${ }^{13,23}$

\section{GAMBARAN MAKROSKOPIS DAN MIKROSKOPIS}

Secara makroskopis seperti terlihat pada gambar 2. Cacing Anisakis sp memiliki karakteristik khas cacing-cacing kelompok nematoda. Meskipun di dalam genus ini terdapat beberapa spesies namun gambaran makroskopisnya sekilas mirip dan sulit dibedakan oleh orang awam.

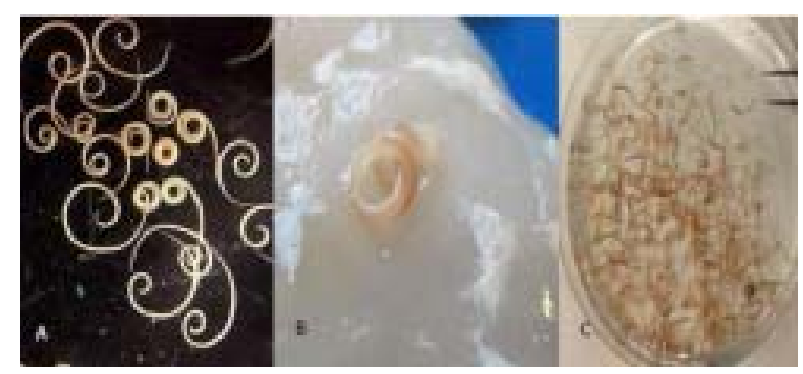

Gambar 2. Gambaran makroskopis larva Anisakis sp. Dengan sedikit perbedaan diantara masingmasing spesies. gbr A. larva A. simplex warna putih semi-transparan, gbr B. larva P.decipiens berwarna coklat kemerahan dan gbr C. larva C. osculatum berwarna abuabu ekecoklatan semi-transparan. ${ }^{7}$ dengan modifikasi
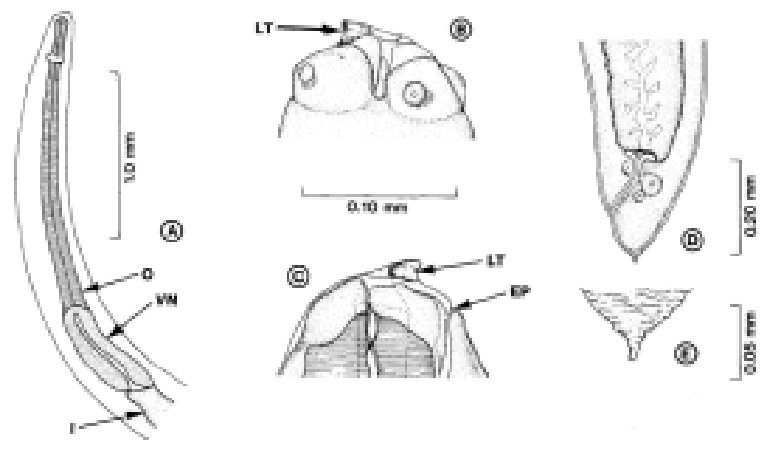

Gambar 3. Skema larva III Anisakis simplex. A aspek anterior, B aspek lateral, C aspek sagittal, D aspek postero-lateral, E perbesaran ekstremitas posterior, tampak mucron. $\mathrm{LT}=$ lateral tooth/gigi lateral, $\mathrm{EP}=$ excretory pore/porus ekskretorius, $\mathrm{IC}=$ intestinal caecum/caecum intestinal, $\mathrm{O}=$ oesophagus, $\mathrm{VN}=$ ventriculus. $^{24, \text { dengan modifikasi }}$ 
Pengamatan secara lebih rinci mengungkapkan perbedaan morfologi antar spesies secara makroskopis seperti yang terlihat pada gambar 3 . baik dari segi warna dan bentuk. Pengamatan, secara mikroskopis mengungkapkan perbedaan antar spesies dalam genus Anisakis sp. Pemahaman mengenai perbedaan bentuk morfologi mikroskopis cacing dalam genus ini masih terus berkembang, seiring dengan penemuan-penemuan baru yang dilaporkan dari berbagai belahan dunia. ${ }^{8,11,12}$

\section{DISTRIBUSI GEOGRAFIS DAN UPAYA PENCEGAHAN}

Distribusi geografis parasit ini salah satunya terjadi melalui pergerakan air lautan atau samudera di dunia, dan dapat ditemukan di semua bagian lautan di wilayah panas maupun dingin, terutama laut dangkal. ${ }^{18-20,25}$ Cakupan sebaran yang luas ini memerlukan upaya analisis dan penilaian kendali atas risiko sehingga dapat mengurangi bahaya bagi masyarakat konsumen. , $^{30,18-23}$ Upaya-upaya pencegahan terus disosialisasikan untuk dilakukan oleh masyarakat, termasuk didalamnya dengan edukasi terhadap pengelola ikan untuk melakukan upaya mekanik seperti ekstirpasi cacing atau larva maupun secara fisiko-thermal melalui pemanasan atau pendinginan untuk membunuh cacing dan juga larva serta upaya lain seperti pembuatan undangundang peraturan pemerintah dan penegakan hukum terkait keamanan pangan untuk mengurangi risiko terjangkitnya infeksi pada manusia akibat mengkonsumsi ikan yang sudah lebih dulu terinfeksi. ${ }^{3,6,7,21,23}$ Upaya ini di Amerika Serikat dilakukan oleh badan pengawasan obat dan makanan nasional yaitu the U.S. Food and Drug Administration, sedangkan di Eropa dilakukan oleh sebuah lembaga independen yang prinsip tugasnya mengawasi dan mengkaji risiko potensi kontaminasi ikan oleh larva cacing ini. ${ }^{22}$ Di Negara Republik Indonesia, terdapat Undang-Undang Nomor 18/2012 tentang pangan yang juga telah mengamanatkan keamanan pangan untuk dikonsumsi. Hal itu dilakukan sebagai upaya untuk mencegah dari kemungkinan cemaran biologis, kimia dan benda lain (termasuk parasit) yang dapat mengganggu, merugikan dan bahkan membahayakan kesehatan manusia. Implementasi UU tersebut akan memastikan setiap produk pangan aman untuk dikonsumsi. ${ }^{1,6}$
Keamanan pangan perlu menjadi perhatian mendasar bagi kesehatan publik. Oleh karena itu belajar dari kasus impor ikan makarel dalam kaleng yang ditemukan mengandung cacing, hasil temuan Badan Pengawas Obat dan Makanan Republik Indonesia (BPOM RI) beberapa tahun yang lalu, upaya meningkatkan keamanan pangan produk perikanan perlu terus dilakukan dan ditingkatkan. Pemerintah Indonesia dalam hal ini diwakili oleh (1) Badan Karantina Ikan, Pengendalian Mutu, dan Keamanan Kementerian Kelautan dan Perikanan (BKIPM KKP), (2) Badan Standardisasi Nasional (BSN) dan (3) BPOM harus terus-menerus bersinergi dalam mewujudkan aturan standar mutu keamanan pangan produk perikanan khususnya bahan baku impor. ${ }^{6}$

Beberapa tahapan yang perlu dilakukan adalah sebagai berikut yaitu (1) seluruh produk perikanan perlu diperlakukan dengan benar. Hal itu dimulai dari semenjak proses di hulu hingga mencapai hilir melalui penerapan good practices di setiap lini proses untuk memenuhi standar mutu dan keamanannya. Kewajiban pemenuhan seluruh persyaratan sanitasi dalam kegiatan atau proses produksi, penyimpanan, pengangkutan dan atau peredaran pangan harus dipastikan telah dilaksanakan. Dalam konteks ini, pengawasan menjadi ujung tombak bagi kendali mutu, (2) tahapan pemantauan dan penapisan terutama bagi komoditas ikan impor, harus semakin diperketat terutama sebelum produk tersebut didistribusikan ke masyarakat. Penerapan berjenjang bagi tingkatan sistem penelusuran (traceability) terhadap bahan baku ikan impor seharusnya mampu dijalankan dengan maksimal. Sebuah produk perikanan dinyatakan memiliki kualitas yang baik jika produk tersebut dapat dilacak asal-usulnya, mulai dari saat penangkapan di laut hingga produk tersebut sampai ke tangan konsumen. Rantai distribusi sebenarnya telah terbentuk dari semenjak proses penangkapan ikan di laut sampai ke tahap retailer dan informasi mengenai asal-usul serta jalur distribusi ikan harus dapat dilacak secara benar. Informasi tersebut mencakup sumber perairan asal ikan, apakah dari perairan tercemar atau tidak bahkan hingga waktu penangkapannya. Ini berdampak pada sistem pencatatan yang harus dilakukan secara metodologis di setiap rantai distribusi. Di sisi lain, komitmen semua pemangku kepentingan/ stake holder untuk sebisa mungkin berupaya menekan ketergantungan 
impor akan kebutuhan bahan baku industri pengolahan ikan yang harus terus menerus dilakukan, dan (3) perlunya revisi standar mutu keamanan pangan oleh Badan Standar Nasional (BSN) yang berwenang mengeluarkan Standar Nasional Indonesia (SNI). Keberadaan standar tersebut direvisi dengan penambahan kewajiban terlaksananya parameter utama standar uji untuk melakukan uji parasit terhadap ikan beku dan ikan kaleng. Mengingat aturan teknis yang diberlakukan BSN soal uji ikan beku dalam SNI 4110.2014 yang sudah ada hanyalah terbatas pada uji kimia, fisika, cemaran mikroba, cemaran logam dan cemaran fisik. Sedangkan parameter uji untuk cacing parasit pada waktu itu mungkin dirasa belum diperlukan. Namun dengan meningkatnya insiden anisakiasis, revisi berupa penambahan parameter uji parasit menjadi suatu keharusan. ${ }^{6}$

\section{Karakteristik Faktor Yang Mempengaruhi Distribusi Parasit}

Laju perkembangan nematoda ini dalam air laut ditentukan terutama oleh suhu. Penurunan suhu air laut mengurangi jumlah larva yang bisa berpenetrasi kedalam otot ikan. ${ }^{26,27}$ Larva cacing ini cenderung lebih banyak di area yang terdapat beragam hospes dalam jumlah banyak seperti di perairan dekat pantai yang memiliki suhu lebih hangat. ${ }^{12,18,27}$ Pola migrasi ikan dapat pula dipelajari dari sebaran parasit Anisakis sp yang diisolasi dari ikan, demikian pula sebaliknya pola distribusi geografis parasit ini dapat diketahui dari tipikal pergerakan inangnya. ${ }^{18,27} \mathrm{Hal}$ tersebut wajar karena secara filosofis, relasi dan transaksi antara parasit dengan inangnya dipengaruhi oleh jumlah dan komposisi masing-masing di alam, jika hospes beragam dan tersedia dalam jumlah yang banyak maka virulensi parasit dapat terus terpelihara dan kelangsungan hidup parasitnya sendiri terjamin karena faktor pasokan ketersediaan makanan yang stabil. $^{28}$

Secara aspek zoonosis-epidemiologis, infeksi oleh cacing Anisakis sp tidak dapat dianggap ringan karena beragamnya spesies hospes yang dapat diinfeksi serta rentang gejala klinis yang ditimbulkannya. ${ }^{29}$ Ikan-ikan yang berperan sebagai hospes tersebut merupakan hospes paratenik yang artinya meskipun mengandung stadium infektif, namun sebenarnya parasit tidak berkembang lebih lanjut. ${ }^{26}$ Namun justru berbahaya jika ikan-ikan yang menjadi hospes paratenik cacing ini kemudian dikonsumsi (baik oleh manusia maupun hewan lain dengan derajat karnivora lebih tinggi) karena adanya potensi melanjutkan perkembangan menjadi stadium dewasa lanjut pada hospes baru. ${ }^{7,8,26,27}$ Ikan laut sebagai hospes paratenik tersebut banyak dikonsumsi oleh organisme dengan taraf hierarki rantai makanan lebih tinggi seperti mammalia laut (singa laut, paus dan lumba-lumba) dan berbagai jenis ikan yang lebih besar dengan kemampuan predatorisme dan karnivora. ${ }^{7,8,26,27}$ Organisme seperti itu terutama berasal dari laut lepas pantai/ laut dalam yang menjadi habitat alamiahnya, yang pada prakteknya juga menjadi salah satu komoditas pangan pokok bagi manusia. $^{30-32}$

Gaya hidup manusia sebagai hospes aksidental anisakiasis juga turut memegang peranan dalam transmisi infeksi, biasanya melalui cara konsumsi bahan makanan yang sudah tercemar atau sudah terinfeksi. ${ }^{33}$ Kesadaran masyarakat perlu terus ditingkatkan lewat edukasi mengenai apa dan bagaimana cara transmisi infeksi. Pemerintah memiliki andil besar dalam menjaga keamanan dan keselamatan konsumen ikan laut. ${ }^{6,33}$

Salah satu moda transmisi adalah melalui perkembangan tren kuliner dan cara memasak saat ini, dimana praktek penyajian/persiapan dan gaya konsumsi ikan dari luar negeri mulai deras masuk dan dipraktekkan sebagai sesuatu yang baru dan menarik (misalnya cara menyiapkan makanan seperti model makanan Jepang Sushi atau Sashimi). ${ }^{34-36}$ Bila produk laut yang tercemar larva tidak dimasak hingga matang atau bahkan dimakan mentah (suatu praktek kuliner yang lazim dilakukan dibeberapa negara) akan memungkinkan larva cacing masih hidup dan dapat menginfeksi manusia. ${ }^{25}$ Disamping itu, kemajuan teknologi bidang pengolahan pangan terutama dalam hal pengalengan ikan dan semakin majunya sistem transportasi memungkinkan meluasnya distribusi atau penyebaran produk laut yang mungkin tercemar Anisakis dp. ${ }^{37}$ Artinya, kemungkinan infeksi dapat terjadi didaerah-daerah yang letaknya jauh dari habitat alamiahnya., Demikianlah faktor perilaku manusia dapat berperan dan mempengaruhi transmisi infeksi parasitik termasuk anisakiasis pada ikan laut. ${ }^{21,38}$ 
PREVALENSI DAN RENTANG SEBARAN ANISAKIASIS PADA IKAN LAUT DI PERAIRAN INDONESIA

Hasil tangkapan laut nelayan di wilayah perairan Indonesia didominasi oleh ikan-ikan yang mempunyai nilai ekonomis tinggi dengan berbagai genre dan kelas konsumen. ${ }^{39}$ Secara bio-hayati, sumber daya ikan yang hidup di wilayah perairan Indonesia dinilai memiliki tingkat keragaman hayati (bio-diversity) paling tinggi di dunia, diperkirakan mencakup 37\% dari spesies ikan di dunia. ${ }^{40}$ Besarnya potensi ekonomis tersebut mendorong pemerintah berupaya mengoptimalkan hasil tangkapan dan produk olahan hasil laut tersebut sehingga meningkatkan kebutuhan konsumsi dimasyarakat. ${ }^{6}$

Di wilayah perairan laut Indonesia terdapat beberapa jenis ikan bernilai ekonomis tinggi seperti tuna, cakalang, udang, tongkol, tenggiri, kakap, cumi-cumi, ikan-ikan karang (kerapu, baronang, udang barong/lobster), ikan hias dan kekerangan termasuk rumput laut. Tingginya permintaan pasar, baik lokal/ dalam maupun luar negeri, mendorong upaya diversifikasi tangkapan guna memasok kebutuhan. ${ }^{39}$

Menurut data Kementerian Kelautan dan Perikanan (KKP) sepanjang tahun 2017, estimasi total produksi perikanan tangkap di wilayah perairan Indonesia mencapai volume 7,67 juta ton atau jika dirupiahkan maka akan setara dengan Rp 158 triliun. ${ }^{41}$ Peningkatan produksi nelayan tangkap juga terus membaik seiring dengan kegiatan pemberantasan kapal asing pencuri ikan yang terus dilakukan. Sehingga memberikan kesempatan bagi stok ikan untuk kembali ber- regenerasi. Berdasarkan data Komisi Nasional (Komnas) pengkajian sumber daya ikan (Kajiskan), potensi stok ikan di perairan Indonesia meningkat signifikan dari 9,93 juta matriks ton pada 2015 menjadi 12,5 juta matriks ton pada 2016. Secara garis besar ini bisa memberikan dampak ekologis bagi komposisi dan interaksi antar biodiversitas, termasuk dalam relasi inang-parasit.

Beberapa penelitian tentang parasit akuatik terutama pada ikan laut menyatakan bahwa, ikan laut yang hidup bebas di alam, khususnya yang bersifat karnivora, sering terinfeksi cacing endoparasit. ${ }^{15}$ Perilaku predator pada mangsanya biasanya merupakan organisme yang ukurannya lebih kecil dari pemangsanya, menyebabkan transmisi infeksi parasitik terjadi. ${ }^{16,28}$ Bahkan saat pergantian hospes/inang tersebut, parasit bisa juga mengalami pertumbuhan hingga menjadi tahapan atau stadium lanjut yang lebih matang. ${ }^{42}$

Berikut disajikan beberapa hasil penelitian mengenai prevalensi anisakiasis pada ikan hasil tangkapan nelayan yang diperoleh dari beberapa wilayah di Indonesia. Metode yang dilakukan penulis untuk mendapatkan informasi mengenai infeksi Anisakis spp pada ikan laut di Indonesia adalah dengan melakukan penelusuran kepustakaan elektronik menggunakan mesin pecari Google ${ }^{\mathrm{TM}}$ dan Yahoo $^{\mathrm{TM}}$. Caranya dengan mengetikkan kata kunci “Anisakis pada ikan laut pdf” pada mesin pencari. Maksud penelusuran menggunakan bahasa Indonesia “Anisakis pada ikan laut” adalah agar yang ditelusuri hanya naskah-naskah berbahasa Indonesia, sedangkan penggunaan pdf dibelakang frasa "Anisakis pada ikan laut" adalah agar data yang ditampilkan oleh mesin pencari hanyalah data yang berada dalam format PDF karena artikel ilmiah elektronik biasanya berada dalam bentuk PDF. 
Tabel 1. Rangkuman berbagai hasil penelitian mengenai isolasi dan prevalensi cacing Anisakis spp. pada produk ikan laut di berbagai wilayah di Indonesia

\begin{tabular}{|c|c|c|c|c|c|}
\hline \multicolumn{2}{|c|}{ No Lokasi } & Spesies ikan & Prevalensi & $\begin{array}{c}\text { Metode } \\
\text { identifikasi }\end{array}$ & Referensi \\
\hline$\overline{1}$ & $\begin{array}{l}\text { Perairan } \\
\text { Mamuju, } \\
\text { Sulawesi Barat }\end{array}$ & $\begin{array}{c}\text { Auxis rochei/tongkol } \\
\text { Decapterus russeli/ikan layang }\end{array}$ & $\begin{aligned} 13 / 30 & =43,3 \% \\
2 / 56 & =3,5 \%\end{aligned}$ & $\begin{array}{ll}\text { 1. } & \text { Morfologi } \\
\text { 2. } & \text { mt-DNAcox-2 } \\
\text { 3. } & \text { Filogenetik }\end{array}$ & $\begin{array}{r}\text { Hafid\& } \\
\text { Anshary, }{ }^{43} \\
2016\end{array}$ \\
\hline 2 & $\begin{array}{l}\text { TPI Ujong } \\
\text { Baroh, Aceh } \\
\text { barat }\end{array}$ & $\begin{array}{l}\text { Euthynnus affinis/ } \\
\text { ikan tongkol }\end{array}$ & $30 / 30=100 \%$ & Morfologi & $\begin{array}{r}\text { Bahri et } a l^{44} \\
2016\end{array}$ \\
\hline 3 & $\begin{array}{l}\text { TPI Pd Dadap, } \\
\text { Kab. Malang }\end{array}$ & Katsuwonus pelamis/ ikan cakalang & $60 \%$ & $\begin{array}{l}\text { 1. Morfologi } \\
\text { 2. Morfometri }\end{array}$ & $\begin{array}{r}\text { Suryani } \\
\text { et al, } \\
2017\end{array}$ \\
\hline 4 & $\begin{array}{l}\text { TPI Pelabuhan } \\
\text { Samudra, } \\
\text { TPI teluk } \\
\text { Penyu,TPI } \\
\text { Lengkong } \\
\text { Cilacap }\end{array}$ & $\begin{array}{l}\text { Kembung } \\
\text { Selar } \\
\text { Swanggi } \\
\text { Tenggiri }\end{array}$ & $\begin{array}{c}10-13,3 \% \\
20-26,7 \% \\
13,3-20 \% \\
3,33 \%\end{array}$ & Morfologi & $\begin{array}{l}\text { Utami, } \\
2014^{46}\end{array}$ \\
\hline 5 & $\begin{array}{l}\text { Perairan } \\
\text { Teluk Kupang }\end{array}$ & $\begin{array}{c}\text { Lates calcarifer/Kakap Putih } \\
\text { Lutjanus sanguineus/Kakap Merah } \\
\text { Epinephelus } \mathrm{sp} / \text { Kerapu }\end{array}$ & $\begin{array}{c}0 \% \\
36,67 \% \\
76,67 \%\end{array}$ & Morfologi & $\begin{array}{r}\text { Paremme et } \\
a l,{ }^{47} \\
2018\end{array}$ \\
\hline 6 & TPI Cilacap & Trichiurus spp/ Layur & $16,67-53,3 \%$ & Morfologi & $\begin{array}{r}\text { Suadi et } a l_{,}^{48} \\
2007\end{array}$ \\
\hline 7 & $\begin{array}{l}\text { Kedonganan, } \\
\text { Badung, Bali }\end{array}$ & Selar crumenophthalmus/ Selar bentong & $80 \%$ & Morfologi & $\begin{array}{l}\text { Tamba et } \\
\text { al, }^{49} 2012\end{array}$ \\
\hline 8 & $\begin{array}{l}\text { TPI pasir } \\
\text { panjang, } \\
\text { Kupang }\end{array}$ & $\begin{array}{l}\text { Katsuwonus pelamis/cakalang } \\
\text { Auxis thazard/tongkol }\end{array}$ & $\begin{array}{l}8 / 50=16 \% \\
10 / 50=20 \%\end{array}$ & $\begin{array}{c}\text { Morfologi } \\
\text { dengan } \\
\text { pewarnaan } \\
\text { Semichen } \\
\text { Acetic Carmine }\end{array}$ & $\begin{array}{r}\text { Hibur et } a l,{ }^{50} \\
2016\end{array}$ \\
\hline 9 & $\begin{array}{l}\text { TPI Glagah, TPI } \\
\text { Bugel, TPI } \\
\text { Trisik, Kulon } \\
\text { progo, } \\
\text { Yogyakarta }\end{array}$ & $\begin{array}{c}\text { Trichiurus lepturu/ Layur } \\
\text { Parupeneus sp./Kuniran } \\
\text { Lutjanus malabaricus/ Tombol } \\
\text { Arius maculatus /Manyung } \\
\text { Teraponjarbua/ Kerong-kerong } \\
\text { Pampus argenteus/ Bawal } \\
\text { Platax orbicularis/Ikan kelelawar } \\
\text { Gymnocranius microdon/Kakap } \\
\text { Drepane punctata/ Ketang } \\
\text { Caesio sp./ ekor kuning } \\
\text { Leiognathus fasciatus/ Peparek }\end{array}$ & $\begin{array}{c}45,83 \% \\
33,3 \% \\
53,8 \% \\
0 \% \\
66,6 \% \\
0 \% \\
0 \% \\
0 \% \\
0 \% \\
50 \% \\
0 \%\end{array}$ & Morfologi & $\begin{array}{l}\text { Setyobudi } \\
\text { et } a l,{ }^{51} 2011\end{array}$ \\
\hline $\begin{array}{l}1 \\
0\end{array}$ & $\begin{array}{l}\text { TPI Brondong, } \\
\text { Lamongan }\end{array}$ & Lutjanus malabaricus/Kakap merah & $66,6-80 \%$ & Morfologi & $\begin{array}{r}\text { Muttaqin et } \\
a l^{52} 2017\end{array}$ \\
\hline $\begin{array}{l}1 \\
1\end{array}$ & $\begin{array}{l}\text { TPI brondong, } \\
\text { Lamongan }\end{array}$ & Rastrelliger brachysoma/ kembung & $9,6 \%$ & Morfologi & $\begin{array}{r}\text { Herman et } \\
a l,{ }^{53} 2014\end{array}$ \\
\hline $\begin{array}{l}1 \\
2\end{array}$ & $\begin{array}{l}\text { TPI Kasiwa, } \\
\text { mamuju }\end{array}$ & $\begin{array}{c}\text { Thunnus albacore/Tuna } \\
\text { Katsuwonus pelamis/cakalang }\end{array}$ & $\begin{array}{c}4 / 30=13,3 \% \\
9 / 30=30 \%\end{array}$ & Morfologi & $\begin{array}{r}\text { Yani\& } \\
\text { Susaniati }^{54} \\
2017\end{array}$ \\
\hline $\begin{array}{l}1 \\
3\end{array}$ & $\begin{array}{l}\text { Teluk banten, } \\
\text { Teluk pel.Ratu }\end{array}$ & $\begin{array}{c}\text { Rastrelliger kanagurta, Rastrelliger } \\
\text { Brachysoma/ ikan kembung }\end{array}$ & $0,9 \%$ & Morfologi & $\begin{array}{r}\text { Indaryanto } \\
\text { et } a l^{55} 2015\end{array}$ \\
\hline
\end{tabular}


1 TPI Lhok Nga

4 Aceh besar

1 TPI Beba,

5 TPI Rajawali, TPI Paotere, makkasar

1 TPI Muara

6 Angke Jakarta Utara

1 Laut

7 kedonganan, Badung, Bali

1 Tambak di

8 Ketapang, Mauk, TangerangBanten

1 TPI Muara

9 angke Jakarta utara

2 TPI brondong,

0 Cilacap

2 TPI brondong,

1 Cilacap

2 TPI Debora,

2 Sibolga, Indonesia.

2 Pelabuhan

3 Perikanan

Pantai

Muncar, Banyuwangi

2 Pantai

4 Selatan Jawa

Timur,

Samudera

Hindia

2 Pasar ikan

5 Kupang,

Nusa

tenggara

timur
Euthynnus affinis/ tongkol

Auxis thazard/ tongkol

Scomber japonicas/ikan salem

Trichiurus lepturus/ ikan layur

Chanos chanos/ikan bandeng

Rastrelliger kanagurta/ ikan kembung

Euthynnus affinis/ ikan tongkol

Trichiurus savala/ ikan layur

Leptorhynchoides sp.

Neoechinorhynchus sp.

Pomphorhynchus sp.

Apororhynchus sp.

ikan tongkol (Euthynnus sp.),

ikan kembung(Rastrelliger sp.),

ikan putihan (Caranx sp.)

ikan kakap (Lutjanus sp.)

Indian mackerel (Rastrelliger spp.)

Epinephelus sp/kerapu

$11 / 50(22 \%)$
$84,4 \%$

$100 \%$ (intestinal)

$10 \%$ (lambung)

$25 \%$ (intestinal)

$25 \%$ (intestinal)

5\% (lambung)

$25 \%$ (intestinal)

Morfologi

Morfologi

Molekuler

utra, 57

2011

Morfologi Pradipta, ${ }^{58}$

2014

Morfologi Semarariana

et $a l,{ }^{59} 2012$

Morfologi Juniardi et

$a l,{ }^{60} 2014$

$25 \%$ (intestinal)

$10 \%$ (intestinal)

$10 \%$ (intestinal)

$25 \%$ (sering)

$50 \%$ (sangat sering)

$6,67 \%$ (kadang)

$66,7 \%$ (sangat

sering)

$17 \%$

Morfologi

pewarnaan

metode

Semichen-

Acetic Carmine

morfologi Setyobudi et

$a l,{ }^{65} 2019$

Ket. TPI=tempat penampungan dan penjualan atau pendaratan ikan 
Dari 25 data hasil penelitian (tabel.1) tentang prevalensi anisakiasis pada ikan laut di berbagai wilayah Indonesia yang didapatkan melalui penelusuran elektronik di mesin pencari Google ${ }^{\mathrm{TM}} \mathrm{dan}$ Yahoo $^{\mathrm{TM}}$ maka dapat dilihat bahwa jenis ikan yang terinfeksi beragam dan semuanya merupakan jenis ikan yang biasa dikonsumsi oleh masyarakat Indonesia, beberapa diantaranya memiliki nilai ekonomis tinggi seperti Euthynnus affinis/ ikan tongkol dan Thunnus albacore/ ikan Tuna, bahkan sudah sampai kepada pasar internasional sebagai salah satu komoditas ekspor andalan hasil laut Indonesia. ${ }^{67}$

Sampel ikan pada 25 penelitian ini didapat dari pasar ikan atau tempat penampungan ikan (TPI) besar di berbagai wilayah Indonesia, dari TPI-TPI tersebut, ikan kemudian disalurkan ke wilayahwilayah sekitarnya untuk dijual ke masyarakat. Hal ini perlu dicermati karena sekalipun tidak mungkin terjadi transmisi antar ikan jika ikan sudah ditangkap dan tidak lagi berada didalam air laut namun ikanikan yang terinfeksi dan tidak dilakukan penapisan untuk mengetahui apakah mengandung cacing atau tidak tetap akan sangat berisiko untuk menyebabkan penyakit pada manusia yang mengkonsumsinya. ${ }^{13,21,23,27}$ Penapisan dan pola distribusi penjualan ikan menjadi salah satu kunci dalam pencegahan risiko., ${ }^{3,12}$

Selain itu, edukasi terhadap konsumen juga perlu ditingkatkan agar konsumen tetap waspada dan berhati-hati dalam membeli ikan, selain itu juga dalam mengolah ikan dengan baik dan benar sebelum dikonsumsi. ${ }^{6}$ Dari hampir seluruh wilayah di Indonesia dalam rentang waktu yang berdekatan, dapat diisolasi larva cacing Anisakis spp pada ikan laut yang ditangkap dan dipasarkan di berbagai TPI di wilayah Republik Indonesia, prevalensi nya beragam bahkan ada yang mencapai $100 \%$ seperti pada sampel ikan Euthynnus affinis/ ikan tongkol di TPI ujong Baroh, Aceh Barat. ${ }^{44} \mathrm{Hal}$ itu menunjukkan bahwa perlu dilakukan penapisan secara lebih serius dan holistik serta berkala/rutin atas ikan-ikan hasil tangkapan dari laut. Upaya itu perlu dilakukan untuk melindungi konsumen dari potensi zoonosis cacing tersebut.

Jika Keseluruh penelitian yang ditampilkan $(\mathrm{n}=25)$ menggunakan metode yang relatif sederhana, yaitu berdasarkan identifikasi morfologis menggunakan mikroskop cahaya. Pemeriksaan ini tidak membutuhkan pewarnaan khusus dan dapat diperiksa secara langsung. ${ }^{13,23}$ Hanya dibutuhkan peralatan sederhana untuk pemeriksaan yaitu cawan petri, kaca objek, gelas penutup dan larutan fisiologis. Bagian-bagian dari cacing Anisakis spp mudah dikenali karena memiliki ciri khas. Larva stadia 3 cacing ini paling sering ditemukan di lambung, rongga abdomen dan otot ikan. ${ }^{43-66} \mathrm{Hal}$ itu menunjukkan, pentingnya pengolahan ikan secara baik dan benar sebelum dikonsumsi supaya konsumen aman tetap terjaga kesehatannya.

Selain itu, aspek lain dari mudahnya melakukan identifikasi morfologis menunjukkan upaya deteksi sebenarnya mudah dilakukan dan murah meskipun secara lege artis prosedur tersebut invasif dan membutuhkan waktu sehingga tentu saja akan merusak tampilan ikan sehingga tidak lagi dapat dikonsumsi, bahkan apalagi diperdagangkan. Hal ini memberikan ruang bagi peneliti atau praktisi perikanan guna menemukan metode penapisan yang nir-invasif dan tidak merusak ikan sebagai komoditas dagang namun tetap dapat memberikan hasil yang terpercaya, cepat, tepat, teruji dan dapat diandalkan. Pengembangan dan penemuan metode tersebut akan terus menjadi tantangan sendiri dalam upaya melindungi kesehatan konsumen secara maksimal.

\section{PENUTUP}

Telah dibahas mengenai anisakiasis secara umum dan pada ikan laut di wilayah perairan Indonesia secara lebih mendalam. Rentang prevalensi dan sebaran infeksi pada ikan laut konsumsi lokal Indonesia dilaporkan secara sporadis dengan kisaran beragam. Kualitas produk ikan yang terinfeksi dan potensi patogenitasnya pada manusia sebagai konsumen menjadi perhatian penting guna perbaikan dalam tatakelola ikan hasil laut sebagai salah satu sumber protein penting bagi masyarakat Indonesia.

\section{DAFTAR PUSTAKA}

1. Adawiyah R, Maryanti E, Siagian FE. Anisakis sp. dan alergi yang diakibatkannya. Jurnal Ilmu Kedokteran. 2014; 8(1): 38-45 
2. Uña-Gorospe M, Herrera-Mozo I, Canals ML, Martí-Amengual G, Sanz-Gallen P. Occupational disease due to Anisakis simplex in fish handlers. Int Marit Health 2018; 69 (4): 264-9

3. Topuz OK, Gokoglu N. Anisakiasis: Parasitic hazard in raw or uncooked seafood products and prevention ways. J Food Health Sci. 2017; 3(1): 21-8 doi: $10.3151 / J F H S 17003$

4. Shimamura Y, Muwanwella N, Chandran S, Kandel G, Marcon N. Common symptoms from an uncommon infection: Gastrointestinal Anisakiasis. Can J Gastroenterol Hepatol. 2016;2016:5176502. doi:10.1155/2016/5176502

5. Aibinu IE, Smooker PM, Lopata AL. Anisakis nematodes in fish and shellfish- from infection to allergies. Int J Parasitol Parasites Wildl. 2019;9:384-393. Published 2019 Jun 6. doi:10.1016/j.jppaw.2019.04.007

6. Daroedono E. Konsumsi ikan dan potensi anisakiasis: aspek komunikasi kesehatan masyarakat suatu program pemerintah. Jurnal Ilmu Kedokteran. 2019; 13(1): 1-10. https:// doi.org/10.26891/JIK.v13i1.2019.4-13

7. Buchmann K, Mehrdana F. Effects of anisakid nematodes Anisakis simplex (s.l.), Pseudoterranova decipiens (s.l.) and Contracaecum osculatum (s.l.) on fish and consumer health. Food and Waterborne Parasitology. 2016; 4. doi:10.1016/ j.fawpar.2016.07.003.

8. Bao M, Pierce G, Pascual S. Assessing the risk of an emerging zoonosis of worldwide concern: anisakiasis. Sci Rep. 2017; 7: 43699. https:// doi.org/10.1038/srep43699

9. Castellanos JA, Santana-Piñeros AM, Mercado R, Peña S, Pustovrh C, Cruz-Quintana Y. Presence of anisakid larvae in commercial fishes landed in the Pacific coast of Ecuador and Colombia. Infectio, 2018; 22(4): 206-12. https:// dx.doi.org/10.22354/in.v22i4.739

10. Dupouy-Camet J. Parasites of cold climates: A danger or in danger?, Food and Waterborne Parasitology. 2016;4:1-3 https://doi.org/10.1016/ j.fawpar.2016.07.004
11. Cole R, Viney M. The population genetics of parasitic nematodes of wild animals. Parasites Vectors 2018; 11, 590. https://doi.org/10.1186/ $\underline{\text { s13071-018-3137-5 }}$

12.ICES. Anisakis larvae ("herringworm"; Nematoda) in fish. Revised and updated by Matt Longshaw. ICES Identification Leaflets for Diseases and Parasites of Fish and Shellfish. Leaflet No. 8. 5 pp. 2012

13.Levsen A, Lunestad BT, Berland B. Low detection efficiency of candling as a commonly recommended inspection method for nematode larvae in the flesh of pelagic fish. Journal of Food Protection, 2005; 68(4): 828-32

14. Mattiucci S, Nascetti G. Molecular systematics, phylogeny and ecology of anisakid nematodes of the genus Anisakis Dujardin, 1845: an update. Parasite.2006;13(2):99-113. Doi: https://doi.org/ 10.1051/parasite/2006132099

15.Kuhn, T., Cunze, S., Kochmann, J. et al. Environmental variables and definitive host distribution: a habitat suitability modelling for endohelminth parasites in the marine realm. Sci Rep. 2016; 6: 30246. https://doi.org/10.1038/ srep3024

16.do Amarante CF, de Souza Tassinari W, Luque JL, Pereira MJS. Parasite abundance and its determinants in fishes from Brazil: an ecoepidemiological approach. Braz. J. Vet. Parasitol., Jaboticabal, 2016; 25(2): 196-201 Doi: http:// dx.doi.org/10.1590/S1984-29612016033

17.Levsen A, Cipriani P, Mattiucci S, Gay M, Hastie $\mathrm{L}$, Mackenzie $\mathrm{K}$, et al. Anisakis species composition and infection characteristics in Atlantic mackerel, Scomber scombrus, from major European fishing grounds - reflecting changing fish host distribution and migration pattern. Fisheries Research. 2017 10.1016/ j.fishres.2017.07.030.

18.Roca-Geronès X, R. Fisa R, Montoliu I. 6. Biogeography of Anisakis (Anisakidae) and Hysterothylacium (Rhaphidascarididae) nematode species in consumed fish. In MuñozTorrero D, Cajal Y, Llobet JM (eds). Recent Advances in Pharmaceutical Sciences VIII, 2018: 95-118 ISBN: 978-81-308-0579-5 
19.Klimpel S, Palm HW. Anisakid Nematode (Ascaridoidea) life cycles and distribution: increasing zoonotic potential in the time of climate change? In Mehlhorn H (ed.), Progress in Parasitology, Parasitology Research Monographs 2, DOI 10.1007/978-3-642-21396-0_11, \# Springer-Verlag Berlin Heidelberg 2011

20.Klimpel S, Kuhn T, Busch M, Karl H,Palm H. Deep-water life cycle of Anisakis paggiae (Nematoda: Anisakidae) in the Irminger Sea indicates kogiid whale distribution in north Atlantic waters. Polar Biology. 2011; 34: 899-906. Doi: 10.1007/s00300-010-0946-1.

21.Pozio E. Integrating animal health surveillance and food safety: the example of Anisakis. Rev. sci. tech. Off. int. Epiz., 2013; 32 (2): 487-96

22. Mladineo I, Poljak V. Ecology and genetic structure of zoonotic Anisakis spp. from adriatic commercial fish species. Appl Environ Microbiol. 2014;80(4):1281-1290. doi:10.1128/AEM.0356113

23.Kochanowski M, Ró ¿ycki M, D ${ }^{1}$ browska J, Bilska-Zaj ${ }^{1} \mathrm{C}$ E, Karamon J, Antolak E, et al. Methods for Anisakis simplex detection in fish and fishery products. Medycyna Weterynaryjna. 2018; 74: 6049-2018. 10.21521/mw.6049. DOI: 10.21521/mw.6049

24. Hurst RJ. Identification and description of larval Anisakis simplex and Pseudoterranova decipiens (Anisakidae: Nematoda) from New Zealand waters, New Zealand Journal of Marine and Freshwater Research, 1984; 18(2), 177-86, DOI: 10.1080/00288330.1984.9516040

25.Costantini E. Anisakis infection in fish: An ecoparasitological study in different fishing grounds of the central-southern Adriatic Sea International Conference on Zoology, Microbiology \& Medical Parasitology October 30-November 01, 2017 | Chicago, USA

26. Strømnes E, Andersen K. Growth of whaleworm (Anisakis simplex, Nematodes, Ascaridoidea, Anisakidae) third-stage larvae in paratenic fish hosts. Parasitol Res. 2003;89(5):335-341. doi:10.1007/s00436-002-0756-7

27. Karl H, Meyer C, Banneke S, Sipos G, Bartelt E, Lagrange F, et al. The abundance of nematode larvae Anisakis sp. in the flesh of fishes and possible post-mortem migration. Archiv fur Lebensmittelhygiene. 2002; 53: 118-20.

28. Cable J, Barber I, Boag B, et al. Global change, parasite transmission and disease control: lessons from ecology. Philos Trans R Soc Lond B Biol Sci. 2017;372(1719):20160088. doi:10.1098/ rstb.2016.0088

29. Æiriæ J, Baltic M, Boškoviæ M, Kilibarda N, Dokmanovic M, Markovic R, et al. Anisakis allergy in human. Trends in Food Science \& Technology. 2017;59:25-9. Doi 10.1016/ j.tifs.2016.11.006.

30.Debenedetti AL, Madrid E, Trelis M, Codes FJ, Gil-Gómez F, Sáez-Durán S, et al. Prevalence and Risk of Anisakid Larvae in Fresh Fish Frequently Consumed in Spain: An Overview. Fishes 2019, 4, 13; doi:10.3390/fishes4010013

31.Linayati Linayati and B D Madusari 2019 IOP Conf. Ser.: Earth Environ. Sci. 399012109

32. Cipriani P, Acerra V, Bellisario B, Sbaraglia GL, Cheleschi R, Nascetti G, et al. Larval migration of the zoonotic parasite Anisakis pegreffii (Nematoda: Anisakidae) in European anchovy, Engraulis encrasicolus: Implications to seafood safety. Food control. 2016;59:148-57 https:// doi.org/10.1016/j.foodcont.2015.04.043

33.Bao M, Pierce GJ, Strachan NJC, Pascual S, González-Muñoz M, Levsen A. Human health, legislative and socioeconomic issues caused by the fish-borne zoonotic parasite Anisakis: Challenges in risk assessment. Trends in Food Science \& Technology, 2019; 86: 298-310, https:/ /doi.org/10.1016/j.tifs.2019.02.013.

34. Oshima T. Anisakiasis - is the sushi bar guilty? Parasitol Today. 1987;3(2):44-48. doi:10.1016/ 0169-4758(87)90212-2

35. Mladineo, Ivona. Anisakiasis in Europe: emerging, neglected, misdiagnosed, or all of the above? 2019;50: 397.

36. Sakanari JA, McKerrow JH. Anisakiasis. Clin Microbiol Rev. 1989;2(3):278-284. doi:10.1128/ cmr.2.3.278

37. Šimat V, Trumbiæ Z. Viability of Anisakis spp. Larvae After Direct Exposure to Different 
Processing Media and Non-Thermal Processing in Anchovy Fillets. Fishes 2019;4 (19). DOI: 10.3390/fishes4010019

38. Williams M, Hernandez-Jover M, Shamsi S. A Critical Appraisal of Global Testing Protocols for Zoonotic Parasites in Imported Seafood Applied to Seafood Safety in Australia. Foods 2020, 9(4), 448; https://doi.org/10.3390/foods9040448

39. White W.T., Last P.R., Dharmadi, Faizah R., Chodrijah U., Prisantoso B.I., Pogonoski J.J., Puckridge M. and Blaber S.J.M. 2013 Market fishes of Indonesia (= Jenis-jenis ikan di Indonesia). ACIAR Monograph No. 155. Australian Centre for International Agricultural Research: Canberra. 438 pp

40. Wahyudin Y, Mulyana D, Ramli A, Rikardi N, Suhartono D Trihandoyo A. Nilai ekonomi keanekaragaman hayati pesisir dan laut Indonesia. Jurnal Cendekia Ihya. 2019; 2(2)

41.Kementerian kelautan dan Perikanan Republik Indonesia. Laporan kinerja 2017. Diunduh dari http://kkp.go.id/an-component/media/uploadgambar-pendukung/kkp/LAPORAN/ Laporan\%20Kinerja\%20KKP\%202017\%20(REV 4 \%20(28Maret).pdf

42. Frainer A, McKie BG, Amundsen PA, Knudsen R, Lafferty KD. Parasitism and the Biodiversity-Functioning Relationship. Trends in Ecology \& Evolution, 2018 Vol. xx, No. yy. https:/ /doi.org/10.1016/j.tree.2018.01.011

43. Hafid MD, Anshary H. Keberadaan Anisakis typica (Anisakidae) dari Ikan Tongkol dan Ikan Layang dari perairan Sulawesi Barat. Jurnal Sain Veteriner 2016; 34(1): 102-111

44. Bahri S. Prevalensi dan intensitas cacing Anisakis sp pada ikan Tongkol (Euthynnus affinis) di TPI Ujongbaroh kecamtan Johan Pahlawan kabupaten Aceh Barat. Skripsi, 2016

45. Suryani EM. Prevalensi dan Intensitas Anisakis sp. Pada Orga Pencernaan Ikan Cakalang (Katsuwonus pelamis) Sebagai Pencegahan Penyakit Zoonosis Anisakiasis. Skripsi. 2017 Jurusan biologi FMIPA Universitas Negeri Malang

46. Utami, P. Identifikasi Anisakis sp. Pada beberapa ikan laut di beberapa Tempat Pelelangan Ikan Cilacap. Jurnal Matematika Sains Dan Teknologi 2014; 15(1): 21-8. Retrieved from https:// jurnal.ut.ac.id/index.php/jmst/article/view/313

47.Paremme AM, Salosso Y, Sunadji. Identifikasi parasit Anisakis sp pada ikan Kakap putih (Lates calcarifer), Kakap merah (Lutjanus sanguineus), dan Kerapu (Epinephelus sp) yang diperoleh di perairan teluk Kupang. Jurnal Grouper 2018; 9(2) https://doi.org/10.30736/ grouper.v9i2.40

48. Suadi, Helmiati S, Widaningroem R. Parasit Anisakis sp pada populasi Layur (Trichiurus sp.) yang didaratkan dipelabuhan ikan Cilacap. J perik (J Fish Sci): IX(2):226-32

49. Tamba MF, Damriyasa IM , Suratma NA, Theisen S. Prevalensi dan distribusi cacing pada berbagai organ ikan Selar Bentong. Indonesia Medicus Veterinus 2012 1(4) : 555-66

50.Hibur O, Detha A, Almet J. Tingkat kejadian parasit Anisakis sp. pada ikan Cakalang (Katsuwonus pelamis) dan ikan Tongkol (Auxis thazard) yang dijual di tempat penjualan ikan Pasir Panjang Kota Kupang. Jurnal Kajian Veteriner, 4(2), 40-51. DOI: https://doi.org/10.35508/ jkv.v4i2.1019

51. Setyobudi E, Soeparno, Helmiati S. Infection of Anisakis sp. larvae in some marine fishes from the southern coast of Kulon Progo, Yogyakarta Biodiversitas 2011;2(1):34-7 DOI: 10.13057/ biodiv/d120107

52. Muttaqin Z, Abdulgani N. Prevalensi dan Derajat Infeksi Anisakis SP. pada Saluran Pencernaan Ikan Kakap Merah (Lutjanus Malabaricus) di Tempat Pelelangan Ikan Brondong Lamongan. Jurnal Sains dan Seni Pomits 2013; 2(1):E30-3 DOI 10.12962/j23373520.v2i1.2745

53.Herman M, Mahasri G, Subekti S. Identifikasi dan prevalensi cacing pada saluran pencernaan ikan Kembung (Rastrelliger brachysoma) di Pelabuhan Perikanan Nusantara Brondong, Lamongan, Jawa Timur. J Aquaculture and fish health. 2014; 3(1 )http://dx.doi.org/10.20473/ jafh.v3i1.12985

54. Yani FI, Susaniati W. infeksi parasit anisakis pada ikan Tuna dan Cakalang di perairan selat 
Makassar. Jurnal galung tropikal. 2017; 3(1) DOI: http://dx.doi.org/10.31850/jgt.v6i3.249

55.Indaryanto FR, Wardiatno Y. Tiuria R. Struktur Komunitas Cacing Parasitik pada Ikan Kembung (Rastrelliger Spp.) di Perairan Teluk Banten dan Pelabuhan Ratu. Jurnal Ilmu Pertanian Indonesia, 2014; 19(1): 1-8. Retrieved from https:// journal.ipb.ac.id/index.php/JIPI/article/view/8399

56. Hidayati N, Muttaqien B, Rusli R, Fahrimal Y, Hambal M, Daud R. Identifikasi parasit pada ikan Tongkol (Euthynnus affinis) di tempat pelelangan ikan Lhoknga Aceh Besar. Jurnal Medika Veterinaria 2016; 10(1)5-8 DOI: 10.21157/j.med.vet..v10i1.4027

57. Saputra LOAR. Deteksi morfologi dan molekuler parasit Anisakis spp pada ikan Tongkol (Auxis thazard ) . Program studi Budidaya Perairan jurusan Perikanan fakultas Ilmu Kelautan dan Perikanan Universitas Hasanuddin Makassar 2011. Skripsi

58. Pradipta RE. Identifikasi dan prevalensi cacing pada saluran pencernaan ikan Salem (Scomber japonicus) di pangkalan pendaratan ikan Muara Angke Jakarta Utara. Universitas Airlangga. 2014 Skripsi

59. Semarariana IWY, Oka IBM, Suratma INA. Infeksi Larva Cacing Anisakis spp. pada Ikan Layur (Trichiurus lepturus) Indonesia Medicus Veterinus 2012; 1(2):293-304

60. Juniardi E, Mustahal M, Putra AN. Inventarisasi cacing parasit pada ikan Bandeng (Chanos chanos) di tambak desa Ketapang kecamatan Mauk kabupaten Tangerang provinsi Banten. Jurnal perikanan dan kelautan 2014; 4(4): 251-7 DOI: http://dx.doi.org/10.33512/jpk.v4i4.173
61.Bauw AR, Mulyana, Mumpuni FS. Inventarisasi parasit pada ikan Kembung (rastreligger kanagurta) di tempat pelelangan ikan Muara Angke jakarta Utara. Jurnal pertanian 2016; 7(1):1-6

62. Rahmawati D. Studi identifikasi dan prevalensi cacing endoparasit pada ikan Layur (Trichiurus savala) di Tempat Pelelangan Ikan (tpi) Brondong kabupaten Lamongan. Fakultas Perikanan dan Kelautan Universitas Airlangga Surabaya 2014 Skripsi

63. Yusni E, Uliya R. Endoparasite worms infestation on Skipjack tuna Katsuwonus pelamis from Sibolga waters, Indonesia. Aceh Journal of Animal Science 2019; 4(2): 61-9

64. Ulkhaq MF, Budi DS, Kenconojati H, Azha MH. Insidensi dan Derajat Infeksi Anisakiasis pada Ikan Hasil Tangkapan di Pelabuhan Perikanan Pantai Muncar, Banyuwangi, Jawa Timur. Jurnal Veteriner, 2019; 20(1): 101-8

65. Setyobudi E, Rohmah I, Syarifa RF, Ramatia L, Murwantoko, Sari DWK. Presence of Anisakis nematode larvae in Indian mackerel (Rastrelliger spp.) along the Indian Ocean southern coast of East Java, Indonesia. B i o d i v e r s i t a s. 2019; 20(1): 313-9

66. Detha A, Wuri DA, Almet J, Melky C. First report of Anisakis sp. in Epinephelus sp. in East Indonesia. Journal of Advanced Veterinary and Animal research. 2018; 5(1):88-92 DOI: 10.5455/ javar.2018.e241

67. Oktavilia S. Competitiveness of Indonesian fishery commodities. 2019 IOP Conf. Ser.: Earth Environ. Sci.246 (2019) 012006 doi:10.1088/17551315/246/1/012006 